\title{
TRANSCRIPTOMIC CHANGES IN RUMINAL TISSUE INDUCED BY THE PERIPARTURIENT TRANSITION IN DAIRY COWS
}

\author{
${ }^{1}$ Louis Dionissopoulos, ${ }^{1}$ Ousama AIZahal, ${ }^{1}$ Michael Alexander Steele, \\ ${ }^{2}$ James Clyde Matthews and ${ }^{1}$ Brian William McBride \\ ${ }^{1}$ Department of Animal and Poultry Science, University of Guelph, Guelph ON N1G2W1, Canada \\ ${ }^{2}$ Department of Animal and Food Sciences, University of Kentucky, Lexington KY, 40546-0215, USA
}

Received 2013-12-24; Revised 2014-01-07; Accepted 2014-01-13

\begin{abstract}
To understand how the capacity for fat metabolism (uptake, synthesis, modification) changes in rumen epithelia immediately before and after onset of lactation in dairy cows, rumen fluid Short Chain Fatty Acid (SCFA) concentrations and mRNA expression profiles of rumen epithelia was determined in twelve Holstein dairy cows at three weeks prior to calving (wk $-3, n=12$ ), one week post calving (week $+1, n=$ 12 ) and six weeks (week $+6, n=12$ ) after calving. The diet was modified from a dry cow formulation to a lactating cow formulation immediately following parturition and raised the non-fiber carbohydrate level from 34 to $43 \%$. All data was analyzed using the mixed procedure of SAS, with cows blocked by anticipated calving date and week of sampling as the repeated measure. Propionate, butyrate, isovalerate and valerate levels rose significantly following the diet change $(\mathrm{p} \leq 0.001)$, although acetate and isobutyrate levels were unchanged $(\mathrm{p}>0.05)$. Mean rumen $\mathrm{pH}$ also changed during the transition period (6.38 Vs 5.81 and $5.85 \pm 0.08 ;-3 \mathrm{Vs}+1$ and +6 ; $\mathrm{p}<0.001)$ as did mean BW (716.00 Vs $635.82 \mathrm{~kg}$ and $615.45 \mathrm{~kg} \pm 16.20 ;-3 \mathrm{Vs}+1$ and $+6 ; \mathrm{p} \leq 0.002)$. Microarray analysis of total RNA from rumen epithelial biopsies revealed 1476 differentially expressed genes at a false discovery rate of $10 \%$. These results were filtered for genes that were directly related to both the immune system and fat metabolism/homeostasis. Consequently, the expression of the resulting 28 genes was analyzed by quantitative PCR (qRT-PCR) to compare their expression at period -3 versus +6 periods. qRT-PCR analysis revealed that 13 genes were upregulated $(\mathrm{p} \leq 0.01), 2$ were downregulated $(\mathrm{p} \leq 0.01)$ and 13 were unchanged during the transition period. Pathway and context analysis yielded a unique interactome pathway map which revealed a set of genomic interactions that indicate a link between selected genes from the immune system and those involved in the preparation for lactation.
\end{abstract}

Keywords: Immune System, Parturition, Transition Period, Fat Metabolism, Microarray, Biological Interactome

\section{INTRODUCTION}

The maintenance of health and the preparation for oncoming parturition is of paramount importance for modern dairy cows during the transition period. As a result, considerable attention has been given to this area of research so that through nutritional interventions and adequate homeostasis of fatty acids, protein and carbohydrate metabolism can be maintained or even enhanced. A comprehensive review of the role of disease in the feeding and management of transition cows can be found in several sources (Mulligan and Doherty, 2008; Mulligan et al., 2006; Overton et al., 2004; Sordillo and Raphael, 2013). Indeed, the literature is replete with information about the role of the liver and adipose tissue in metabolic alterations during parturition (Loor, 2010). Yet despite its importance to ruminant physiology, genomic adaptations in the rumen underlying these processes have largely been ignored (Loor, 2010).

During the immediate few weeks following parturition, genomic changes take place which promote Corresponding Author: Brian William McBride, Department of Animal and Poultry Science, University of Guel
ON N1G 2W1, Canada Tel: +1 (519) 824-4120 ext. 53695 Fax: +1 (519) 836-9873 
the production of milk at the expense of normal body maintenance (Ingvartsen, 2006). These changes are hallmarked by clear reductions in body condition score and dry matter intake in the modern dairy cow, so it is clear that a massive mobilization of nutrients must be taking place which is orchestrated by an as yet unknown series of mechanisms (Adrien et al., 2012). However, excellent information continues to be reported on tissues known to play important roles in these processes (liver and adipose). As a result of low feed intake, circulating insulin concentrations are low and result in drastic reductions in lipogenesis through alterations in the control pathways that regulate them (Ji et al., 2012; Leroy et al., 2008), enabling more nutrients available for milk production. These changes can be effectively tracked by studying genomic changes in key metabolic pathways and so, relative changes in gene expression can be used as a tool to track energy status in the periparturient dairy cow.

The advent of high throughput screening technologies such as microarray and quantitative PCR in the past few years has allowed researchers to amass a large database of information on global gene expression from a wide variety of conditions such as disease or drug treatment (Cao et al., 2006; Galindo et al., 2010). Using such technologies has allowed for the delineation of many disease processes and has enhanced our knowledge of the biochemistry of metabolic adaptations. Because most data concerning nutrient partitioning in the peri-parturient dairy cow has come from studies of liver and adipose tissue, there is a scarcity of genomic data concerning changes in the rumen during this time period. In dairy cattle, the rumen is the principle site of SCFA generation and although de novo fatty acid synthesis takes place primarily in adipose tissue in these animals, it is the rumen which is the primary control point for the entry of nutrients into the body (Laliotis et al., 2010). Indeed, our group has previously reported genomic changes related to cholesterol homeostasis in the rumen of dairy cattle (Steele et al., 2011b). Moreover, we recently reported that major structural changes in the rumen are facilitated by components of the immune system (Dionissopoulos et al., 2013). In order to help better understand the physiological changes that take place during the peripartal period, changes in gene expression of key nutrient metabolic pathways should be elucidated. The objective of the current study was to determine the magnitude and identification of genomic changes in the rumen related to nutrient (fat) homeostasis and energy availability.

\section{MATERIALS AND METHODS}

\subsection{Animals, Treatments and Diet}

Twelve dairy primiparous (mean wt. $644 \pm 13 \mathrm{~kg}$ ) and multiparous (mean wt. $760 \pm 10 \mathrm{~kg}$ ) Holstein dairy cows fitted with rumen cannulae (Duffield, 1999) were used in this study and were housed in a tie-stall facility at the Elora Dairy Research Station, University of Guelph. The animal utilization protocol (10R105) was approved for use by the University of Guelph Animal Care Committee in accordance with guidelines set forth by the Canadian Council on Animal Care. The cows were placed within the study three weeks prior to calving (-3) and were placed on a lactating cow diet immediately following parturition through the 6th week thereafter. The cows were fed a Total Mixed Ration (TMR) twice daily at 08:00 and 14:00, where the amount of feed allocated to the cows was monitored to allow for a maximum of $5 \mathrm{~kg} \mathrm{day}^{-1}$ of orts on an as-fed basis. The diet formulations and their chemical composition are presented in Table 1.

\subsection{Rumen SCFA and $\mathrm{pH}$}

Rumen fluid was collected at the same time each day (approximately $3 \mathrm{~h}$ after the last feeding; 17:00) from the ventral sac of the rumen and squeezed through 4 layers of cheesecloth into $50 \mathrm{~mL}$ capped, conical centrifuge tubes and frozen for subsequent analysis of SCFA via gas chromatography (Dionissopoulos et al., 2013). Rumen $\mathrm{pH}$ was spot measured on the last two days of each experimental week (week $-3,+1$ and +6 ), (AlZahal et al., 2007). Mean daily $\mathrm{pH}$ for each experimental week was calculated and tabulated in Table 2.

\subsection{Rumen Papillae Biopsies, Microarray and qRT-PCR}

Samples of rumen papillae $(n=12)$ were harvested from the ventral sac of the rumen at the end of each experimental week according to the methodology described in Steele et al. (2012b). Rumen contents were partially evacuated to allow access to the ventral sac. Approximately $150 \mathrm{mg}$ of papillae was cut from this area and washed 20 times in ice-cold PBS and subsequently placed in RNAlater ${ }^{\mathrm{TM}}$ (Qiagen, Hilden, GmbH) until such time that the RNA could be isolated. Total tissue RNA was isolated as previously described by our group (Steele et al., 2012b) using the RNeasy midi kit (Qiagen, Mississauga, Ontario, Canada) and its concentration was determined by Nano-Drop (ND-1000, NanoDrop Technologies, Wilmington, Delaware). After isolation, the RNA was treated with DNAse (Invitrogen, Inc., Burlington, Ontario, Canada) and its purity was assessed 
using a bio-analyzer (Agilent 2100, Agilent Technologies Inc., Palo Alto, California).

\subsection{Microarray}

The isolated RNA was subsequently prepared for microarray analysis to determine expression differences $(n=12)$ between weeks -3 and +6 . Microarray hybridization and data acquisition was performed at the University of Kentucky Advanced Genomic Technologies Center using the 24K Affymetrix GeneChip Bovine array (Affymetrix, Santa Clara, CA) as was done previously (Steele et al., 2011b). The effect of week of transition on gene expression was assessed at the University of Guelph Genomics Facility using GeneSpring GX 7.3.1 (Agilent Technologies, Santa Clara, CA). Using the partial least squares methodology in SAS (2004), comparison differences were determined between the two weeks, employing a false discovery rate of 0.1 according to the methods of Benjamini as described by Reiner et al. (2003). Therefore, differences expressed between treatment weeks at an adjusted $\mathrm{P}$ value $<0.10$ were considered to be significant.

\section{5. qRT-PCR}

In order to confirm results on candidate genes involved in fat homeostasis and the immune system, quantitative PCR was performed on samples from the -3 $(\mathrm{n}=12)$ and $+6(\mathrm{n}=12)$ periods. Five $\mu \mathrm{g}$ samples were reverse transcribed using iTaq SYBR Green (Bio-Rad Laboratories) performed in triplicate using an ABI Prism 7000 instrument (Applied Biosystems). Where permissible, PCR primers were designed to span exonexon junctions using the NCBI/PrimerBLAST tool (http://www.ncbi.nlm.nih.gov/tools/primer-blast) and were verified to be specific for target genes using GenBank (NCBI, Bethesda, Maryland). Primer efficiency was determined through a 5-point standard curve method, where these dissociation curves were used to determine the amplification of a single gene product. Target gene expression was normalized to GAPDH mRNA expression which was used as the housekeeping gene (Steele et al., 2011a), where GAPDH stability was confirmed by low variance Ct. Differences in the expression of genes assessed by qRT-PCR were determined using the Pfaffl et al. (2004). mRNA content was expressed relative to the -3 week observation as described previously (Xue et al., 2010). Expression differences were assessed via the comparison of individual +6 week group samples to the -3 pooled value using a Student's t-test. All differentially expressed genes were analyzed for interaction pathways using the Ingenuity Pathway Analysis software tool (Ingenuity Inc., Redwood
City, California) in conjunction with the University of Kentucky (Lexington, Kentucky). Values deemed significant were subjected to a screen of $95 \%$ confidence and a false discovery rate of $10 \%$ according to the methods of Benjamini (Reiner et al., 2003).

\subsection{Statistical Analysis}

SCFA concentration, BW, BCS and $\mathrm{pH}$ were analyzed using the Mixed procedure in SAS (2004). This model included cow parity (primi-or multiparous) and week $(-3$, $+1,+6)$. The term "week" was used as the repeated measurement using "cow" as the subject term and the data was subjected to multiple covariance structures. The structure that yielded the smallest Bayesian information criterion was used for reporting of results.

\section{RESULTS}

\subsection{Diet and Physiological Parameters}

Table 1 indicates the formulation and chemical composition (analysis) of the diet in this study. As can be seen in the table, the analysis confirmed that the design actually matched the composition for both of the diets.

Table 1. Formulation and chemical composition of pre-and post-parturient TMR diets expressed on an a dry matter basis)

\begin{tabular}{lcc}
\hline & $\%$ DM & \\
& Dry-cow & Lactating-cow \\
Component & 45.00 & 26.00 \\
\hline Corn silage & 11.00 & 26.00 \\
Alfalfa silage & 27.00 & 6.00 \\
Straw & - & 20.00 \\
High-moisture corn & 18.00 & 21.00 \\
Protein supplement $^{1}$ & & \\
Chemical composition & 44.00 & 45.00 \\
DM, \% & 13.00 & 16.00 \\
CP (N×6.25) & 5.00 & 6.00 \\
Soluble Protein & 3.00 & 4.00 \\
ADIN & 31.00 & 23.00 \\
ADF & 46.00 & 34.00 \\
NDF & 34.00 & 43.00 \\
NFC & 18.00 & 22.00 \\
Starch & 3.00 & 3.00 \\
Ether extract & 8.00 & 7.00 \\
Ash & 1.37 & 1.68 \\
NE & Mcal/kg &
\end{tabular}

${ }^{\mathrm{T}}$ Dry-cow protein supplement contained 48\%-soybean meal, $10 \%$ canola meal, $10 \%$ wheat bran, $19 \%$ vitamin and mineral mix, $4 \%$ soybean hulls, $2 \%$ molasses, $3 \%$ beef tallow. Lactating cow supplement contained $9 \%$ high-protein corn gluten meal, $48 \%$ soybean meal, $7 \%$ Tri-Pro Gold, $14 \%$ canola meal, $10 \%$ beat pulp, $3 \%$ herring meal, $4 \%$ dry-corn distillers grain, $12 \%$ mineral mix, $5 \%$ soybean hulls, $2 \%$ molasses, $3 \%$ beef tallow 
There was no effect of transition period ( $-3 \mathrm{vs}+1 \mathrm{vs}+6)$ on rumen acetate and isobutyrate concentrations or on total SCFA concentration (Table 2). However, propionate was significant between weeks -3 and +1 (17.57 vs 22.94), between weeks -3 and $+6(17.57$ Vs 22.26), but not between weeks +1 and $+6(22.94$ vs $22.26 \pm 1.25 \mathrm{mM})$. For weeks -3 $\mathrm{Vs}+1$ and for weeks -3 vs +6 , Butyrate (6.97 Vs $9.85 \pm 0.52$ $\mathrm{mM})$, isovalerate $(1.09 \mathrm{Vs} 1.29 \pm 0.07 \mathrm{mM})$ and valerate (1.74 Vs. $2.57 \pm 0.15 \mathrm{mM}$ ) concentrations were affected by diet transition (Table 2; $\mathrm{p} \leq 0.004$ ). No statistical differences were observed between weeks +3 vs +6 .

Similarly, mean rumen $\mathrm{pH}$ changed significantly between weeks -3 and $+1(6.38$ vs $5.81 \pm 0.08$; $p<0.001)$ and between weeks -3 and $+6(6.38$ Vs $5.85 \pm 0.08 ; \mathrm{p}<0.001)$. As was the case with the SCFA, no changes were observed in the comparisons between weeks +1 and +6 .

Body weight and BCS (data not shown) also significantly changed between week -3 and $+1(716.00$ vs. $635.82 \pm 16.20 ; \mathrm{P}=0.002)$ and between week -3 and +6 (716.00 vs. $615.45 \pm 16.20 ; \mathrm{p}<0.001)$. BW and BCS did not change between weeks +1 and +6 .

\subsection{Microarray Screen, qRT-PCR and Pathway Analysis}

Microarray analysis of total rumen papillae RNA revealed that 1476 genes were differentially expressed
( $p<0.0001$; data not shown). Subsequently, the 1476 differentially expressed genes (10\% FDR) were subjected to a stringent screening regimen in which only those genes related to nutrient homeostasis and the immune system were chosen. In addition, only those differentially expressed genes in which a direct interactive relationship was demonstrated in the literature and were found in the GIT were subjected to verification by qRT-PCR. The 28 genes found to correspond to these criteria which demonstrated microarray-identified differential expression, were confirmed by qRT-PCR. Of those, 13 were upregulated (ACSL1, ATF3, CLU, DUSP1, EPAS1, F2RL1, GSN, MAP2K1, MAPK3, PTEN, SMAD4, SREBF1 and TP63), 2 were downregulated (HMOX1 and LGALS1) and 13 were unchanged (BCL2L11, CAV1, HIF1A, HTR2A, KSR1, MIF, PPARA, PRKCD, SERPINE1, STAT4, TGFB1, TIMP1 and VDR). Gene expression results along with fold changes and significance are presented in Table 3. In addition, an interpretation is offered which places meaning on these results within a contextual interactome framework of the genes which intersect those involved in fat metabolism and those commonly associated with the immune system. Using these results and the IPA tool, a concrete graphical interactome was constructed and can be seen in Fig. 1.

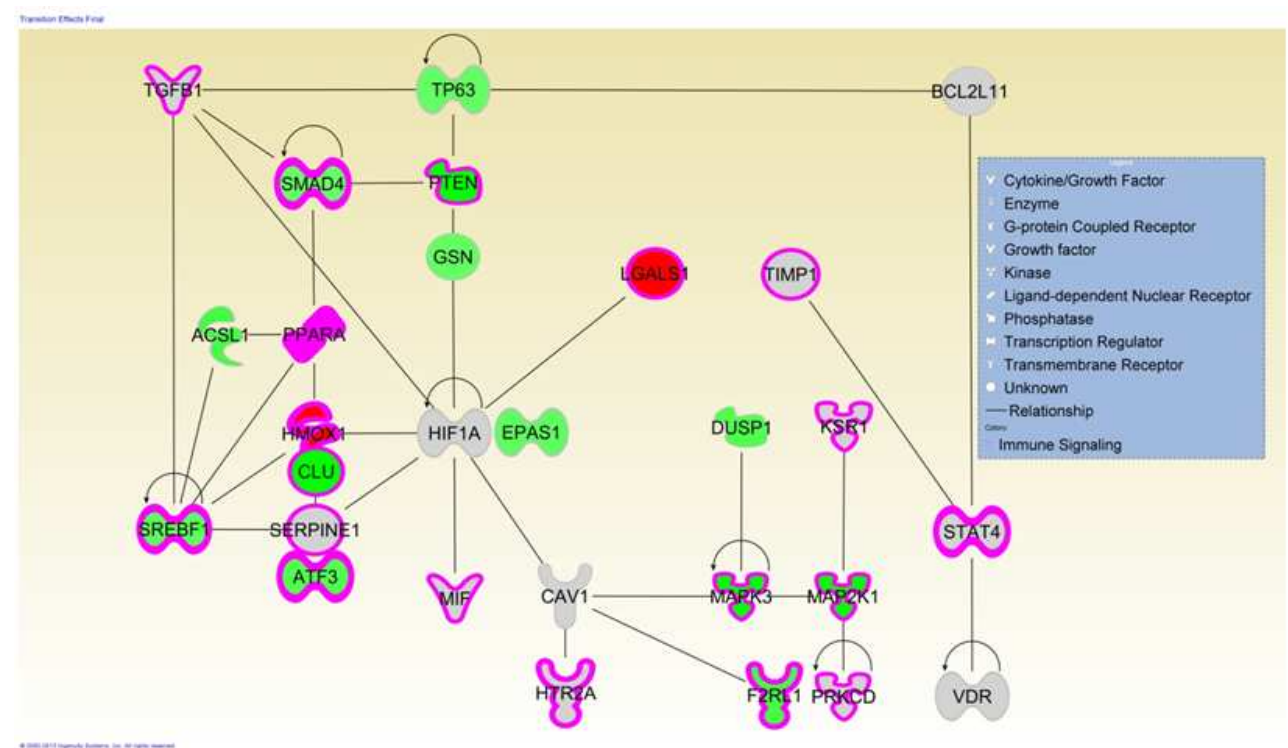

Fig. 1. Biological interactome pathway delineated by genomic analysis of immune-related and fat metabolism genes in the bovine rumen using Ingenuity Pathway Analysis. Findings were analysed using ANOVA and mixed models statistics and biological network analysis stemming from microarray and qRT-PCR analysis of 1476 differentially expressed genes (false discovery rate $10 \%$ ). These results were further filtered to include only those genes that were confirmed to be direct interactions and related to both the immune system and fat metabolism in the gastrointestinal tract of mammals from Table 3 Green = upregulated gene; Red = downregulated gene; Gray = unaffected. Genes outlined in magenta indicate concomitant involvement in immune system signaling 
Table 2. Rumen SCFA concentration (mM), mean rumen $\mathrm{pH}$ and mean Body Weight (BW; $\mathrm{kg}$ ) expressed through the transition period $(-3,+1$ and +6 weeks $)$. Values are expressed as means \pm SEM; $n=12$ per treatment week.

\begin{tabular}{|c|c|c|c|c|c|c|c|}
\hline & \multirow{2}{*}{$\begin{array}{l}\text { Day -3 } \\
\text { A }\end{array}$} & \multirow{2}{*}{$\begin{array}{l}\text { Day }+1 \\
\text { B }\end{array}$} & \multirow{2}{*}{$\begin{array}{l}\text { Day }+6 \\
\text { C }\end{array}$} & \multirow[b]{2}{*}{ SEM } & \multicolumn{3}{|l|}{ P-value } \\
\hline & & & & & $\mathrm{AB}$ & $\mathrm{AC}$ & $\mathrm{BC}$ \\
\hline Total SCFA & 70.61 & 73.48 & 81.90 & 4.43 & 0.645 & 0.0870 & 0.195 \\
\hline Acetate & 40.75 & 40.53 & 43.20 & 1.32 & 0.911 & 0.2390 & 0.200 \\
\hline Propionate & 17.57 & 22.94 & 22.26 & 1.25 & 0.001 & 0.0040 & 0.643 \\
\hline Isobutyrate & 2.48 & 2.68 & 2.95 & 0.17 & 0.394 & 0.0640 & 0.282 \\
\hline Butyrate & 6.97 & 9.85 & 9.40 & 0.52 & $<0.001$ & 0.0020 & 0.510 \\
\hline Isovalerate & 1.09 & 1.29 & 1.43 & 0.07 & 0.005 & $<0.0001$ & 0.039 \\
\hline Valerate & 1.74 & 2.57 & 2.47 & 0.15 & $<0.001$ & $<0.0010$ & 0.592 \\
\hline $\mathrm{pH}$ & 6.38 & 5.81 & 5.85 & 0.08 & $<0.001$ & $<0.0010$ & 0.730 \\
\hline BW & 716.00 & 635.82 & 615.45 & 16.20 & 0.002 & $<0.0010$ & 0.381 \\
\hline
\end{tabular}

Table 3. Gene expression results from qRT-PCR analysis and biological context analysis from rumen tissue of cows from the transition period between weeks -3 and +6 . All pathway results were confirmed via the INGENUITY ${ }^{\mathrm{TM}}$ KEGG knowledge database

\begin{tabular}{|c|c|c|c|c|c|c|}
\hline Symbol & Entrez Gene Name & Fold Change & SE & P-value & Function & Ref. \\
\hline ACSL1 & acyl-CoA synthetase long -chain family member 1 & 1.54 & 0.53 & 0.01 & Promotes uptake of rumen SCFA & (Yang and Barouch, 2007) \\
\hline ATF3 & activating transcription factor 3 & 3.13 & 0.57 & 0.00 & Promotes assimilation of fatty acids & (Zmuda et al., 2010) \\
\hline BCL2L11 & BCL2-like 11 (apoptosis facilitator) & Unchanged & NA & NS & NA & \\
\hline CAV1 & caveolin 1 , caveolae protein, $22 \mathrm{kDa}$ & Unchanged & NA & NS & NA & \\
\hline CLU & clusterin & 1.33 & 0.10 & 0.01 & Promotes fat mobilization & (Seo et al., 2013) \\
\hline DUSP1 & dual specificity phosphatase 1 & 2.09 & 0.27 & 0.00 & Promotes fat mobilization & (Guenard et al., 2013) \\
\hline EPAS1 & endothelial PAS domain protein 1 & 1.72 & 0.21 & 0.00 & $\begin{array}{l}\text { Improves insulin sensitivity } \\
\text { and fat mobilization }\end{array}$ & (Shimba et al., 2004) \\
\hline F2RL1 & coagulation factor II (thrombin) receptor-like 1 & 2.10 & 0.20 & 0.00 & Promotes fat mobilization & (Badeanlou et al., 2011) \\
\hline GSN & gelsolin & 1.65 & 0.19 & 0.00 & $\begin{array}{l}\text { Promotes mammary gland } \\
\text { Development }\end{array}$ & (Crowley et al., 2000) \\
\hline HIF1A & $\begin{array}{l}\text { hypoxia inducible factor 1, alpha subunit } \\
\text { (basic helix -loop- helix transcription factor) }\end{array}$ & Unchanged & NA & NS & NA & \\
\hline HMOX1 & heme oxygenase (decycling) 1 & 0.75 & 0.06 & 0.00 & Promotes efflux of hepatic triglycerides & (Czech et al., 2013) \\
\hline HTR2A & $\begin{array}{l}\text { 5-hydroxytryptamine (serotonin) receptor } 2 \mathrm{~A} \text {, } \\
\text { G protein-coupled }\end{array}$ & Unchanged & NA & NS & NA & \\
\hline KSR1 & kinase suppressor of ras 1 & Unchanged & NA & NS & NA & \\
\hline LGALS1 & lectin, galactoside-binding, soluble, 1 & 0.72 & 0.08 & 0.00 & Promotes glucose homeostasis & (Camby et al., 2006) \\
\hline MAP2K1 & mitogen-activated protein kinase kinase 1 & 1.36 & 0.05 & 0.00 & Maintains fat homeostasis & (Bost et al., 2005) \\
\hline MAPK3 & mitogen-activated protein kinase 3 & 1.40 & 0.14 & 0.01 & Promotes adipogenesis & (Bost et al., 2005) \\
\hline MIF & $\begin{array}{l}\text { macrophage migration Inhibitory factor } \\
\text { (glycosylation-inhibiting factor) }\end{array}$ & Unchanged & NA & NS & NA & \\
\hline PPARA & $\begin{array}{l}\text { peroxisome proliferator } \\
\text {-activated receptor alpha }\end{array}$ & Unchanged & NA & NS & NA & \\
\hline PRKCD & protein kinase $\mathrm{C}$, delta & Unchanged & NA & NS & NA & \\
\hline PTEN & phosphatase and tensin homolog & 1.44 & 0.11 & 0.00 & Promotes fat mobilization & (Sanchez-Gurmaches et al., 2012) \\
\hline SERPINE1 & $\begin{array}{l}\text { serpin peptidase inhibitor, clade } \mathrm{E} \text { (nexin, } \\
\text { plasminogen activator inhibitor type } 1 \text { ), member } 1\end{array}$ & Unchanged & NA & NS & NA & \\
\hline SMAD4 & SMAD family member 4 & 1.65 & 0.14 & 0.00 & Maintains fat homeostasis & (Wrana, 2009) \\
\hline SREBF1 & $\begin{array}{l}\text { sterol regulatory element } \\
\text { binding transcription factor } 1\end{array}$ & 2.29 & 0.27 & 0.00 & $\begin{array}{l}\text { Promotes de novo fat } \\
\text { synthesis and mobilization }\end{array}$ & (Eberle et al., 2004) \\
\hline STAT4 & signal transducer and activator of transcription 4 & Unchanged & NA & NS & NA & \\
\hline TGFB1 & transforming growth factor, beta 1 & Unchanged & NA & NS & NA & \\
\hline TIMP1 & TIMP metallopeptidase inhibitor 1 & Unchanged & NA & NS & NA & \\
\hline TP63 & tumor protein p63 & 1.73 & 0.14 & 0.00 & Promotes fatty acid synthesis & (Sabbisetti et al., 2009) \\
\hline VDR & vitamin $\mathrm{D}(1,25$-dihydroxyvitamin $\mathrm{D} 3)$ receptor & Unchanged & NA & NS & NA & \\
\hline
\end{tabular}

\section{DISCUSSION}

The transition period for a high-producing dairy cow is metabolically stressful and it is during this time that most production diseases occur (Drackley, 1999; Ji et al., 2012;
Osorio et al., 2013), most likely as a result of transient but sustained immunosuppression (Springer and Sciences, 2008). Many metabolomic and genomic studies have been performed to determine the role of macronutrients on gene expression of key metabolic pathways (Loor, 2010; 
Mulligan and Doherty, 2008; Mulligan et al., 2006). However, these studies have mainly focused on liver and adipose tissue, largely ignoring the rumen epithelium. As the rumen is the source for most metabolic SCFA and nutrient transport and since immune activity seems to be omnipresent, we elected to elucidate changes in transition cow rumen epithelial tissue by studying local genomic alterations to determine what role, if any, is ascribed to the immune system.

\subsection{Physiological Parameters}

To achieve optimal health status during the transition period, the diet of the dairy cow must be modified to balance production goals while maintaining adequate health (NRC, 2001). As the cow progresses through the transition period, its diet changes from one typical of a dry cow formulation to one which is formulated for lactating cows (Grummer, 1995). The dietary formulations in this study follow this treatment paradigm, changing in such key parameters as protein level, ADF, energy density and most drastically, NFC (Table 1). In this study, the NFC content rose from $34 \%$ to $43 \%$, a diet typically used for lactating dairy cows, but which is known to cause Subacute Ruminal Acidosis (SARA) (Dionissopoulos et al., 2012; Steele et al., 2012a). The rise in NFC over the transition period reflects the change in mean $\mathrm{pH}$ over time; where it was seen to drop from 6.38 to approximately 5.81 following a dietary switch post-calving. Although still below the threshold level for a diagnosis of SARA (Plaizier et al., 2008), the changes in $\mathrm{pH}$ likely reflect dietary alterations and hence changes in SCFA homeostasis rather than a physiological adaptation during the transition period. In addition to BW losses from calf, placenta and fluid expulsion, as expected, BW decreased significantly during the transition period, falling significantly from $716 \mathrm{~kg}$ to $635 \mathrm{~kg}$. Negative changes in BW and body condition score have been associated with the transition period and have been documented for some time (Hutjens and Aalseth, 2005). It is important to note that the ensuing inflammation that occurs following calving can also be a contributing factor to reductions in DMI. Chronic immune system stimulation during this period has been known to result in anorexia, leading to feed depressions and reductions in body weight (Dionissopoulos et al., 2006; Esposito et al., 2013).

Although the total rumen SCFA did not change, the ruminal SCFA propionate, butyrate, isovalerate and valerate showed significant increases that coincided with the timing of the dietary change post calving. It is known that ruminal SCFA concentration is largely affected by dietary formulation and nutrient ecology (Aschenbach et al., 2011; Gabel and Sehested, 1997; Kristensen et al., 1998; Penner et al., 2011) and not as an adaptive mechanism during the transition period. The SCFA concentrations agree with previously published reports from our group using diets of similar composition (Dionissopoulos et al., 2013; Steele et al., 2012b).

\subsection{Gene Expression and Biological Interactome Analysis}

The changes accompanying the rumen epithelium in the transition cow have been largely ignored, due to the importance of metabolically active tissues such as liver and adipose (Loor, 2010). Yet this amazing tissue is the site of a great variety and quantity of nutrient absorption and so likely serves a significant role during the transition period in the high-producing dairy cow. Our group therefore, sought to determine genomic alterations in ruminal tissue during this period. To achieve this goal, a microarray screen followed by qRT-PCR analysis was performed on genes differentially expressed and associated with fat metabolism and the immune response. Furthermore, since we have previously shown a role for the immune system in facilitating rumen adaptation (Dionissopoulos et al., 2013), it was deemed prudent to also determine which immune-related genes were undergoing change. In this study, the genes significantly changed and verified by qRT-PCR were related to the immune system and fat metabolism (mobilization, synthesis).

Receptor signaling in adipose and liver tissues is known to enhance insulin sensitivity and fatty acid homeostasis during the postpartum period (Loor, 2010). In addition, the principle means by which metabolic alterations take place are through changes in a multitude of pathways involved in fatty acid homeostasis, with glucose and amino acid homeostasis following close behind (Dann et al., 2006; Drackley et al., 2006; Loor et al., 2006). Hence, since adipose tissue contains the key metabolic fuel for mobilization in the periparturient dairy cow, its signaling pathways must be of high concern as they are likely to affect fat metabolism in distant tissues (Vernon, 2005).

ACSL1 and SREBF1, which were upregulated during the transition period, are both involved in enhancing the uptake and assimilation of rumen SCFA (Yang et al., 2007) and in de novo fatty acid synthesis and mobilization. These results agree with those published earlier this year (Weber et al., 2013) which showed similar patterns of expression during the transition 
period. ATF3 is an inducible transcription factor whose expression is enhanced by high levels of circulating fatty acids and glucose (Zmuda et al., 2010). ATF3 expression was enhanced in this study, which corresponds to its role in promoting the mobilization of fatty acids. CLU is a gene expressed in various tissues, but most notably its expression is reduced during lactation and is partially responsible for mammary gland involution following the cessation in lactation during the dry period (Piantoni et al., 2010). CLU was upregulated in our study, owing to the fact that comparisons were made among the interval between -3 and +6 weeks post calving, which presented the greatest differences. DUSP1 along with MAP2K1 and MAPK3 are well known genes involved in nutrient homeostasis. DUSP1 has been reported to be one of a series of upstream regulators of the MAP series of kinase activity (Liu et al., 2008) and has been shown to be downregulated during a shift from negative to positive energy balance (Moyes et al., 2011), likely affecting downstream transcription of MAP2K1 and MAPK3. These results agree with those presented here in that during transition, cows in general are in a negative energy balance state. Similarly, EPAS1 has been shown to improve insulin sensitivity and fat homeostasis (Shimba et al., 2004) and in this study, EPAS1 was upregulated during the transition period, likely as a response to the negative energy balance described above. F2RL1 and PPAR2 are central signaling genes and originate from the signal clotting cascade in a wide variety of tissues (Reinhardt et al., 2012). In the present study, F2RL1 expression increased likely as a result of MAPK signaling in negative energy balance. In an experimental model of obesity, Badeanlou et al. (2011) found that mice lacking the F2RL1 gene had better fat homeostasis and insulin sensitivity than their wild type counterparts. GSN is a cytoskeletal protein involved in actin signaling in order to strengthen and prepare the bovine mammary interstitium for lactation (Crowley et al., 2000). In the rumen, its upregulation may also be a response to a negative energy balanced state in order to mobilize body reserves for a successful lactation (Kuhla et al., 2011). Moreover, PTEN (upregulated in our study) is also a key gene in the pathway mediating fat liberation during this period (Sanchez-Gurmaches et al., 2012) and in response to increased levels of SMAD4 and control inputs from TGF- $\beta$ and TP63 signaling (Wrana, 2009), acts through PPARA and back to ACSL1 to mediate the liberation of fats from metabolic stores and to promote the redistribution of energy to on-demand tissues.

To better understand the interconnectedness and adaptability of metabolism, a biological interactome was derived (Fig. 1) using data obtained from this study as well as from the Ingenuity Systems ${ }^{\mathrm{TM}}$ KEGG database (Tanabe and Kanehisa, 2012; Zhou, 2013). As can be seen in Fig. 1, these genes act in a concerted fashion to regulate fat metabolism and hence energy availability. A central role for this pathway in the provision of energy during the transition period can clearly be seen.

\section{CONCLUSION}

To our knowledge, this is the first analysis of metabolic and genomic markers of ruminal tissue of dairy cows during the transition period. Although the transition period places severe metabolic and physical stress on the dairy cow, through changes in the expression of genes involved in fat metabolism, the immune system and energy homeostasis, the dairy cow can have a productive and healthy life. We have demonstrated altered expression of a subset of genes that seem to constitute an interactome representing associated changes in the expression of genes responsible for fatty acid, triglyceride and immune system capacity, which collectively prepare the dairy cow for the metabolic rigors associated with the transition period.

\section{ACKNOWLEDGEMENT}

The researchers would like to acknowledge ongoing financial support from the Ontario Ministry of Agriculture Food and Rural Affairs, Dairy Farmers of Canada and the National Sciences and Engineering Research Council of Canada. We would also like to thank Anne Laarman, Katie Wood, Erin Hendrikson, Holly McGill, Adam Kleinberg, Jing Zhang with the University of Guelph Genomics Facility and the staff of the Ponsonby Research Station (University of Guelph) for their help and dedication during this study.

\section{REFERENCES}

Adrien, M.L., D.A. Mattiauda, V. Artegoitia, M. Carriquiry and G. Motta et al., 2012. Nutritional regulation of body condition score at the initiation of the transition period in primiparous and multiparous dairy cows under grazing conditions: Milk production, resumption of post-partum ovarian cyclicity and metabolic parameters. Animals, 6: 292-299.

AlZahal, O., B. Rustomo, N.E. Odongo, T.F. Duffield and B. W. McBride, 2007. Technical note: A system for continuous recording of ruminal $\mathrm{pH}$ in cattle. $\mathrm{J}$. Anim. Sci., 85: 213-217. DOI: 10.2527/jas.2006-095 
Aschenbach, J.R., G.B. Penner, F. Stumpff and G. Gabel, 2011. Ruminant nutrition symposium: Role of fermentation acid absorption in the regulation of ruminal pH. J. Anim. Sci., 89: 1092-1107. DOI: 10.2527/jas.2010-3301

Badeanlou, L., C. Furlan-Freguia, G. Yang, W. Ruf and F. Samad, 2011. Tissue factor-protease-activated receptor 2 signaling promotes diet-induced obesity and adipose inflammation. Nat. Med., 17: 14901497. DOI: $10.1038 / \mathrm{nm} .2461$

Bost, F., M. Aouadi, L. Caron, P. Even and N. Belmonte et al., 2005. The extracellular signal-regulated kinase isoform ERK1 is specifically required for in vitro and in vivo adipogenesis. Diabetes, 54: 402411. DOI: $10.2337 /$ diabetes.54.2.402

Camby, I., M. Le Mercier, F. Lefranc and R. Kiss, 2006. Galectin-1: A small protein with major functions. Glycobiology, 16: 137R-157R. DOI: 10.1093/glycob/cwl025

Cao, H., L.C. Kabaroff, Q. You, A. Rodriguez, H. J. Boermans and N. A. Karrow, 2006. Characterization of ovine hepatic gene expression profiles in response to Escherichia coli lipopolysaccharide using a bovine cDNA microarray. BMC Vet. Res., 2: 34. DOI: $10.1186 / 1746-6148-2-34$

Crowley, M.R., K.L. Head, D.J. Kwiatkowski, H.L. Asch and B.B. Asch, 2000. The mouse mammary gland requires the actin-binding protein gelsolin for proper ductal morphogenesis. Dev. Biol., 225: 407423. DOI: $10.1006 /$ dbio. 2000.9844

Czech, B., I.D. Neumann, M. Muller, S.O. Reber and C. Hellerbrand, 2013. Effect of chronic psychosocial stress on nonalcoholic steatohepatitis in mice. Int. J. Clin. Exp. Pathol., 6: 1585-1593. PMID: 23923077

Dann, H.M., N.B. Litherland, J.P. Underwood, M. Bionaz and A. D'Angelo et al., 2006. Diets during far-off and close-up dry periods affect periparturient metabolism and lactation in multiparous cows. J. Dairy Sci., 89: 3563-3577. DOI: 10.3168/jds.S00220302(06)72396-7

Dionissopoulos, L., A.H. Laarman, O. AlZahal, S.L. Greenwood and M.A. Steele et al., 2013. Butyratemediated genomic changes involved in non-specific host defenses, matrix remodeling and the immune response in the rumen epithelium of cows afflicted with subacute ruminal acidosis. Am. J. Anim. Vet. Sci., 8: 8-27. DOI: 10.3844/ajavsp.2013.8.27

Dionissopoulos, L., C.E. Dewey, H. Namkung and C.F.M. de Lange, 2006. Interleukin-1ra increases growth performance and body protein accretion and decreases the cytokine response in a model of subclinical disease in growing pigs. Anim. Sci., 82: 509-515. DOI: 10.1079/ASC200654
Dionissopoulos, L., M.A. Steele, O. AlZahal, J.C. Plaizier and B.W. McBride, 2012. A characterization of inflammatory and structural markers within the rumen epithelium during grain-induced ruminal acidosis in lactating dairy cattle. Am. J. Anim. Vet. Sci., 7: 141148. DOI: 10.3844/ajavsp.2012.141.148

Drackley, J. K., S.S. Donkin and C.K. Reynolds, 2006. Major advances in fundamental dairy cattle nutrition. J. Dairy Sci., 89: 1324-1336. DOI: 10.3168/jds.S0022-0302(06)72200-7

Drackley, J.K., 1999. Biology of dairy cows during the transition period: The final frontier? J. Dairy Sci., 82: 2259-2273. DOI: 10.3168/jds.S0022-0302(99)75474-3

Duffield, T., 1999. A fistful of rumen--a novel approach to rumen fistula surgery. Proceedings of the Annual Convention, (PAC' 99), American Association of Bovine Practitioners, pp: 179-179.

Eberle, D., B. Hegarty, P. Bossard, P. Ferre and F. Foufelle, 2004. SREBP transcription factors: Master regulators of lipid homeostasis. Biochimie, 86: 839848. DOI: 10.1016/j.biochi.2004.09.018

Esposito, G., P.C. Irons, E.C. Webb and A. Chapwanya, 2013. Interactions between negative energy balance, metabolic diseases, uterine health and immune response in transition dairy cows. Anim. Reproduct. Sci. DOI: 10.1016/j.anireprosci.2013.11.007

Gabel, G. and J. Sehested, 1997. SCFA transport in the forestomach of ruminants. Comp. Biochem. Physiol. Physiol., 118: 367-374. DOI: 10.1016/S03009629(96)00321-0

Galindo, R.C., N. Ayllon, T. Carta, J. Vicente and K.M. Kocan et al., 2010. Characterization of pathogenspecific expression of host immune response genes in Anaplasma and Mycobacterium species infected ruminants. Comp. Immunol. Microbiol. Infect. Dis., 33: e133-142. DOI: 10.1016/j.cimid.2010.09.001

Grummer, R.R., 1995. Impact of changes in organic nutrient metabolism on feeding the transition dairy cow. J. Anim. Sci., 73: 2820-2833. PMID: 8582873

Guenard, F., L. Bouchard, A. Tchernof, Y. Deshaies and F.S. Hould et al., 2013. DUSP1 gene polymorphisms are associated with obesity-related metabolic complications among severely obese patients and impact on gene methylation and expression. Int. J. Genomics. DOI: 10.1155/2013/609748

Hutjens, F. and P. Aalseth, 2005. Caring for z. W.D. Hoard and Sons.

Ingvartsen, K.L., 2006. Feeding- and managementrelated diseases in the transition cow: Physiological adaptations around calving and strategies to reduce feeding-related diseases. Anim. Feed Sci. Technol., 126: 175-213. DOI: 10.1016/j.anifeedsci.2005.08.003 
Ji, P., J.S. Osorio, J.K. Drackley and J.J. Loor, 2012. Overfeeding a moderate energy diet prepartum does not impair bovine subcutaneous adipose tissue insulin signal transduction and induces marked changes in peripartal gene network expression. J. Dairy Sci., 95: 4333-4351. DOI: 10.3168/jds.2011-5079

Kristensen, N.B., A. Danfaer and N. Agergaard, 1998. Absorption and metabolism of short-chain fatty acids in ruminants. Arch. Tierernahr., 51: 165-175. DOI: 10.1080/17450399809381916

Kuhla, B., G. Nurnberg, D. Albrecht, S. Gors, H.M. Hammon and C.C. Metges, 2011. Involvement of skeletal muscle protein, glycogen and fat metabolism in the adaptation on early lactation of dairy cows. J. Proteome Res., 10: 4252-4262. DOI: 10.1021/pr200425h

Laliotis, G.P., I. Bizelis and E. Rogdakis, 2010. Comparative approach of the de novo fatty acid synthesis (Lipogenesis) between ruminant and non ruminant mammalian species: From biochemical level to the main regulatory lipogenic genes. Curr. Genomics, 11: 168-183. $\quad$ DOI: $10.2174 / 138920210791110960$

Leroy, J., T. Vanholder, A.T.M. Van Knegsel, I. GarciaIspierto and P.E.J. Bols, 2008. Nutrient prioritization in dairy cows early postpartum: Mismatch between metabolism and fertility? Reproduct. Domestic Anim., 43: 96-103. DOI: 10.1111/j.1439-0531.2008.01148.x

Liu, Y.X., J. Wang, J. Guo, J. Wu, H. B. Lieberman and Y. Yin. 2008. DUSP1 is controlled by p53 during the cellular response to oxidative stress. Mol. Cancer Res., 6: 624-633. DOI: 10.1158/1541-7786.MCR-07-2019

Loor, J.J., 2010. Genomics of metabolic adaptations in the peripartal cow. Animal., 4: 1110-1139. DOI: 10.1017/S1751731110000960

Loor, J.J., H. M. Dann, N.A. Guretzky, R.E. Everts and R. Oliveira et al., 2006. Plane of nutrition prepartum alters hepatic gene expression and function in dairy cows as assessed by longitudinal transcript and metabolic profiling. Physiol. Genomics, 27: 29-41. DOI: 10.1152 /physiolgenomics.00036.2006

Moyes, K.M., J.K. Drackley, D.E. Morin, S.L. Rodriguez-Zas and R.E. Everts et al., 2011. Predisposition of cows to mastitis in non-infected mammary glands: effects of dietary-induced negative energy balance during mid-lactation on immune-related genes. Funct. Integr. Genomics, 11: 151-156. DOI: 10.1007/s10142-010-0186-Z

Mulligan, F.J. and M.L. Doherty, 2008. Production diseases of the transition cow. Vet. J., 176: 3-9. DOI: $10.1016 /$ j.tvj1.2007.12.018
Mulligan, F.J., L. O'Grady, D.A. Rice and M.L. Doherty, 2006. A herd health approach to dairy cow nutrition and production diseases of the transition cow. Anim. Reprod. Sci., 96: 331-353. DOI: 10.1016/j.anireprosci.2006.08.011

NRC, 2001. Nutrient Requirements of Dairy Cattle. 1st Edn., National Academy Press, Washington, D.C.

Osorio, J.S., P. Ji, J. K. Drackley, D. Luchini and J. J. Loor, 2013. Supplemental smartamine $\mathrm{m}$ or metasmart during the transition period benefits postpartal cow performance and blood neutrophil function. J. Dairy Sci., 96: 6248-6263. DOI: 10.3168/jds.2012-5790

Overton, T.R. and M.R. Waldron, 2004. Nutritional management of transition dairy cows: Strategies to optimize metabolic health. J. Dairy Sci., 87: E105E119. DOI: 10.3168/jds.S0022-0302(04)70066-1

Penner, G. B., M. A. Steele, J. R. Aschenbach and B.W. McBride, 2011. Ruminant nutrition symposium: Molecular adaptation of ruminal epithelia to highly fermentable diets. J. Anim. Sci., 89: 1108-1119. DOI: $10.2527 /$ jas.2010-3378

Pfaffl, M.W., A. Tichopad, C. Prgomet and T.P. Neuvians, 2004. Determination of stable housekeeping genes, differentially regulated target genes and sample integrity: BestKeeper--Excel-based tool using pairwise correlations. Biotechnol. Lett., 26: 509-515. DOI: 10.1023/B:BILE.0000019559.84305.47

Piantoni, P., P. Wang, J. K. Drackley, W.L. Hurley and J.J. Loor, 2010. Expression of metabolic, tissue remodeling, oxidative stress and inflammatory pathways in mammary tissue during involution in lactating dairy cows. Bioinform. Biol. Insights, 4: 85-97. PMID: 20981268

Plaizier, J.C., D.O. Krause, G.N. Gozho and B.W. McBride, 2008. Subacute ruminal acidosis in dairy cows: the physiological causes, incidence and consequences. Vet. J., 176: 21-31. DOI: 10.1016/j.tvj1.2007.12.016

Reiner, A., D. Yekutieli and Y. Benjamini, 2003. Identifying differentially expressed genes using false discovery rate controlling procedures. Bioinformatics, 19: 368-375. DOI: 10.1093/bioinformatics/btf877

Reinhardt, C., M. Bergentall, T. U. Greiner, F. Schaffner and G. Ostergren-Lunden et al., 2012. Tissue factor and PAR1 promote microbiota-induced intestinal vascular remodelling. Nature, 483: 627-631. DOI: 10.1038/nature10893

Sabbisetti, V., A. Di Napoli, A. Seeley, A. M. Amato and E. O'Regan et al., 2009. p63 promotes cell survival through fatty acid synthase. PLoS One, 4: e5877. DOI: 10.1371/journal.pone.0005877 
Sanchez-Gurmaches, J., C.M. Hung, C.A. Sparks, Y. Tang, H. Li and D.A. Guertin, 2012. PTEN loss in the Myf5 lineage redistributes body fat and reveals subsets of white adipocytes that arise from Myf5 precursors. Cell Metab., 16: 348-362. DOI: 10.1016/j.cmet.2012.08.003

SAS, 2004. SAS/STAT User's Guide Release 9.1. 1st Edn., SAS Institute Inc., Cary, NC.

Seo, H.Y., M.K. Kim, Y.A. Jung, B.K. Jang and E.K. Yoo et al., 2013. Clusterin decreases hepatic SREBP-1c expression and lipid accumulation. Endocrinology, 154: 1722-1730. DOI: 10.1210/en.2012-2009

Shimba, S., T. Wada, S. Hara and M. Tezuka, 2004. EPAS1 promotes adipose differentiation in 3T3-L1 cells. J. Biol. Chem., 279: 40946-40953. DOI: 10.1074/jbc.M400840200

Sordillo, L.M. and W. Raphael, 2013. Significance of metabolic stress, lipid mobilization and inflammation on transition cow disorders. Vet. Clin. North Am. Food Anim. Pract., 29: 267-278. DOI: 10.1016/j.cvfa.2013.03.002

Springer, H.R. and I.S.U.B. Sciences, 2008. Effect of pre-calving diet energy content on immunologic and metabolic parameters in the transition cow. MSc Thesis, Science Iowa State University.

Steele, M.A., J. Croom, M. Kahler, O. AlZahal, S.E. Hook, K. Plaizier and B.W. McBride, 2011a. Bovine rumen epithelium undergoes rapid structural adaptations during grain-induced subacute ruminal acidosis. Am. J. Physiol. Regul. Integr. Comp. Physiol., 300: R15151523. DOI: 10.1152/ajpregu.00120.2010

Steele, M.A., G. Vandervoort, O. AlZahal, S.E. Hook and J.C. Matthews et al., 2011b. Rumen epithelial adaptation to high-grain diets involves the coordinated regulation of genes involved in cholesterol homeostasis. Physiol. Genom., 43: 308316. DOI: 10.1152/physiolgenomics.00117.2010

Steele, M.A., O. Alzahal, M.E. Walpole and B.W. McBride, 2012a. Short communication: Graininduced subacute ruminal acidosis is associated with the differential expression of insulin-like growth factor-binding proteins in rumen papillae of lactating dairy cattle. J. Dairy Sci., 95: 6072-6076. DOI: $10.3168 /$ jds.2011-4864

Steele, M.A., L. Dionissopoulos, O. AlZahal, J. Doelman and B.W. McBride, 2012b. Rumen epithelial adaptation to ruminal acidosis in lactating cattle involves the coordinated expression of insulin-like growth factor-binding proteins and a cholesterolgenic enzyme. J. Dairy Sci., 95: 318-327. DOI: $10.3168 /$ jds.2011-4864
Tanabe, M. and M. Kanehisa, 2012. Using the KEGG Database Resource. In: Current Protocols in Bioinformatics.

Vernon, R.G., 2005. Lipid metabolism during lactation: A review of adipose tissue-liver interactions and the development of fatty liver. J. Dairy Res., 72: 460469. DOI: $10.1017 /$ S0022029905001299

Weber, C., C. Hametner, A. Tuchscherer, B. Losand and E. Kanitz et al., 2013. Hepatic gene expression involved in glucose and lipid metabolism in transition cows: Effects of fat mobilization during early lactation in relation to milk performance and metabolic changes. J. Dairy Sci., 96: 5670-5681. DOI: $10.3168 /$ jds.2012-6277

Wrana, J.L., 2009. The secret life of Smad4. Cell, 136: 13-14. DOI: 10.1016/j.cell.2008.12.028

Xue, Y., S.F. Liao, K.W. Son, S.L. Greenwood and B.W. McBride et al., 2010. Metabolic acidosis in sheep alters expression of renal and skeletal muscle amino acid enzymes and transporters. J. Anim. Sci., 88: 707-717. DOI: $10.2527 /$ jas.2009-2101

Yang, C.S., D.S. Lee, C.H. Song, S.J. An and S. Li et al., 2007. Roles of peroxiredoxin II in the regulation of proinflammatory responses to LPS and protection against endotoxin-induced lethal shock. J. Exp. Med., 204: 583-594. DOI: 10.1084/jem.20061849041807c

Yang, R. and L.A. Barouch, 2007. Leptin signaling and obesity: Cardiovascular consequences. Circ. Res., 101: 545-559. DOI: 10.1161/CIRCRESAHA.107.156596

Zhou, T., 2013. Computational reconstruction of metabolic networks from KEGG. Methods Mol. Biol., 930: 235-249. DOI: 10.1007/978-1-62703059-5_10

Zmuda, E.J., L. Qi, M.X. Zhu, R.G. Mirmira, M.R. Montminy and T. Hai, 2010. The roles of ATF3, an adaptive-response gene, in high-fat-dietinduced diabetes and pancreatic beta-cell dysfunction. Mol. Endocrinol., 24: 1423-1433. DOI: $10.1210 / \mathrm{me} .2009-0463$ 